\title{
KEPEMIMPINAN PESANTREN
}

\section{Kajian Integrasi Budaya Pesantren Dan Budaya Dayak Di Pondok Pesantren Hidayatul Insan Fii Ta'limiddin Kota Palangka Raya}

\author{
Ahmadi \\ Institut Agama Islam Negeri Palangka Raya \\ Email: ahmadiiainplk@yahoo.co.id
}

\begin{abstract}
This study examines the leadership of the Kiai at the Hidayatul Insan Islamic Boarding School, Fii Ta'Limiddin, Palangka Raya City with the formulation of the nature of pesantren leadership and how to integrate Islamic boarding school culture and Dayak culture in the Hidayataul Insan Islamic Boarding School, Palangka Raya City. The research was conducted using a phenomenological approach through interviews, observation, and documentation techniques. Data analysis was carried out through three activity streams. The results showed that the leadership of the pesantren is a leadership phenomenon that tends to be autocracy in which the highest power and authority is in the hands of the Kiai. Integrative leadership as a cooperative and democratic leadership model can be an alternative model of leadership, especially in the context of cultural integration in Islamic boarding schools.
\end{abstract}

Keywords: Leadership, Kiai, Cultural Integration, Islamic Boarding School

\begin{abstract}
Abstrak
Penelitian ini mengkaji kepemimpinan kiai di Pondok Pesantren Hidayatul Insan Fii Ta'Limiddin Kota Palangka Raya dengan rumusan bagaimana hakikat kepemimpinan pesantren dan bagaimana integrasi budaya pesantren dan budaya Dayak di Pondok Pesantren Hidayataul Insan Kota Palangka Raya. Penelitian dilakukan dengan menggunakan pendekatan fenomenologis melalui teknik wawancara, observasi dan dokumentasi. Analisis data dilakukan melalui melalui tiga alur kegiatan. Hasil penelitian menunjukkan jika Kepemimpinan pesantren merupakan fenomena kepemimpinan yang cenderung autocracy di mana kekuasaan dan kewenangan tertinggi ada di tangan kiai. Kepemimpinan integratif sebagai model kepemimpinan yang koperatif dan demokratis dapat menjadi alternatif model kepemimpinan terutama dalam konteks integrasi budaya di pondok pesantren.
\end{abstract}

Kata Kunci: Kepemimpinan, Kiai, Integrasi Budaya, Pondok Pesantren 


\section{A. Pendahuluan}

Pondok pesantren dengan segala fenomenanya merupakan sesuatu yang sangat menarik untuk dikaji. Lembaga pendidikan Islam ini memiliki karakteristik yang sangat berbeda dengan institusi pendidikan lainnya, baik dari aspek sejarah dan perkembangannya, komponen kelembagaan, hingga pola pendidikannya (Soebahar, 2013:33). Salah satu komponen penting dari pesantren adalah figur kiai. Kiai sebagai pimpinan tertinggi di pesantren memiliki kewibawaan dan otoritas yang hampir mutlak. Betapa tidak, di lingkungan pesantren tidak ada orang yang paling dihormati daripada kiai (Geertz, 1960:232). Sikap hormat dan kepatuhan mutlak kepada kiai merupakan nilai pertama yang ditanamkan pada setiap santri. Penghormatan dan kepatuhan itu bahkan dianggap lebih penting daripada usaha menguasai ilmu itu sendiri, karena hal tersebut merupakan bagian integral dari pembelajaran di pondok pesantren (Bruinessen, 2015:86). Kiai merupakan figur sentral yang menjadi acuan bagi santrinya dalam berbagai aspek kehidupan pesantren. Secara sosiologis, kedudukan kiai mirip dengan kedudukan raja. Kiailah yang memiliki, mempertahankan, mengasuh dan mengembangkan pesantren (Qomar, 2005:23). Dengan demikian, pertumbuhan sebuah pesantren sangat bergantung pada kepemimpinan kiainya.

Fenomena kepemimpinan kiai di setiap pesantren memiliki karateristik yang berbeda-beda sesuai dengan dimensi ruang dan waktu di mana pesantren tersebut berada. Sebab, seorang pemimpin sebagaimana juga kiai tidak berdiri sendiri dalam memimpin sebuah organisasi (pesantren), tetapi ia terikat dengan faktor lain, yakni situasi (situation) termasuk di dalamnya tugas, tekanan, lingkungan dan lain sebagainya serta pengikut (followers) yang terdapat di dalamnya normanorma, nilai-nilai, keterpaduan dan lain-lain (Hughes \& Curphy, 2002:24). Teori modern memandang suatu organisasi sebagai suatu sistem yang terdiri dari input, proses, output (arus balik) dan lingkungan (Wisnu dan Nurhasanah, 2005:117), sebagaimana Siagian (1987:81) menyebutkan bahwa kepemimpinan tidak pernah bergerak dan berfungsi dalam suasana yang vakum. Ia bersifat situasional, kondisional, temporal atau dengan kata lain banyak faktor yang mempengaruhi efektivitas kepemimpinan seseorang, Oleh sebab itu, salah satu unsur yang dapat 
menyebabkan kepemimpinan menjadi lebih efektif adalah kemampuan adaptis seorang pemimpin terhadap lingkungan sosial budaya dan kemampuan membangun relationship yang baik dengan budaya-budaya yang ada di sekitarnya.

David Whitfiled menyatakan bahwa kompetensi kultural merupakan salah satu syarat yang harus dimiliki seorang pemimpin yang berwawasan global. Seorang pemimpin harus memahami bukan hanya akar budayanya sendiri, tetapi juga akan akar budaya orang lain, mengerti isu yang relevan, dan mampu bekerjasama dengan berbagai macam karakter orang di mana memiliki budaya yang berbeda dengan budaya dirinya sendiri (Whitfield, 2004:2). Menurut Abdul Azis Wahab dalam Aimah dan Ekaningsih (2017) strategi utama dalam kepemimpinan adalah kemampuan pemimpin menjalalnkan fungsi sebagai anggota organisasi. Dengan kata lain strategi hanya dapat dilaksanakan secara baik apabila diawali dengan sikap dan prilaku pemimpin yang mampu menempatkan dirinya sebagai bagian dari anggota organisasinya. Mengenai hal ini ada empat karakteristik utama seorang pemimpin yaitu inteligensi, kematangan dan kekuasaan dalam pandangan sosial, memiliki motivasi dan keinginan maju, memiliki kemampuan berprestasi

Peran kiai sebagai pimpinan pondok pesantren menjadi semakin kompleks manakala lembaga ini hadir sebagai "tamu" di lingkungan masyarakat yang memiliki adat istiadat, tradisi dan kebudayaan yang ketat, seperti masyarakat Suku Dayak di Kota Palangka Raya. Sensitivitas kiai dalam melihat nilai-nilai budaya lokal serta progresivitas dalam berinteraksi menjadi sangat diperlukan untuk harmonisasi dan kebertahanan pondok pesantren. Sebab jika tidak, maka kecil kemungkinan pesantren tersebut akan mampu bertahan. Hal ini sebagaimana yang dikemukakan Vianen bahwa pendatang baru yang memiliki perbedaan persepsi terhadap budaya (organisasi) yang berhubungan dengan komitmen dan tujuan organisasi, tidak akan mampu bertahan di organisasi tersebut (Vianen, 2000:13).

Kehadiran pondok pesantren di Kota Palangka Raya merupakan bagian dari pergulatan sejarah yang menarik dalam konteks interreligiousdialogue dan toleransi serta penyebaran Islam di Kalimantan Tengah. Di satu sisi, Suku Dayak 
Ngaju sebagai penduduk asli Kota Palangka Raya dan agama Kaharingan (agama lokal) berada pada pusaran perkembangan agama-agama baru, Hindu, Budha, Kristen, dan Islam. Di sisi lainnya, suku Dayak berusaha mempertahankan adat istiadat, budaya, filosofi, dan kekeluargaan, serta kearifan lokal.

Pondok Pesantren Hidayatul Insan Fii Ta'Limiddin Kota Palangka Raya (yang selanjutnya disebut Pondok Pesantren HI Kota Palangka Raya) merupakan sebuah institusi pendidikan Islam yang hadir di tengah-tengah masyarakat plural di Kota Palangka Raya. Pondok pesantren yang berdiri sejak tahun 1987 ini masih tetap survive dan bahkan menjadi pesantren "terbesar" yang ada di Kota Palangka Raya. Pondok Pesantren HI terletak di pinggiran sungai dengan bangunan asrama santri dan tempat belajar nampak tidak tertata dengan rapi dan masih berupa bangunan dari kayu. Area pondok pesantren ini juga menyatu dengan permukiman penduduk yang memiliki kultur beragam, bahkan tidak ada pembatas yang memisahkan area pondok pesantren dari lingkungan masyarakat.

Kondisi ini menjadikan Pondok Pesantren HI sebagai lembaga pendidikan Islam yang inklusif. Di tengah-tengah iklim sosial budaya yang multikultural dan terkesan kurang kondusif, pondok pesantren ini dapat menjalankan aktivitas pembelajaran dengan baik, kegiatan-kegiatan ekstra kurikuler seperti olah raga, kesenian, pramuka dan lain-lain berjalan sebagaimana adanya. Keberadaaan Pondok Pesantren HI Palangka Raya selama kurang lebih tiga dekade, telah memainkan peranan strategis sebagai agent of change bagi proses kaderisasi keislaman di Kota Palangka Raya. Pondok pesantren ini juga mampu eksis dan bersaing prestasinya dengan sekolah-sekolah unggulan di Kota Palangka Raya baik secara akademik maupun non akademik.

Kepemimpinan kiai dalam mengintegrasikan budaya pesantren dan budaya Dayak di pesantren tidak terlepas dari pandangan visioner kiai tentang eksistensi dan tantangan dunia pesantren di era globalisasi dewasa ini. Di sisi lain, perlunya model pesantren yang menghargai local wisdom demi kebertahanan pesantren di tengah masyarakat suku Dayak yang memiliki tradisi dan adat istiadat yang ketat. Upaya perubahan terhadap pola pesantren dengan melakukan integrasi budaya tersebut dimulai dengan memahami konteks budaya Dayak, proses eksternalisasi 
dan adaptasi, hingga strategi dalam menginternalisasi nilai, norma, attitude budaya Dayak di pondok pesantren. Dalam upaya mengatasi perbedaan bahasa, kiai secara otodidak berusaha mempelajari dan menggunakan bahasa Dayak Ngaju yang banyak digunakan oleh mayoritas masyarakat Suku Dayak di Kota Palangka Raya. Kemampuan kiai menggunakan bahasa Dayak sebagai bahasa masyarakat setempat sangat membantu dalam proses interaksi personal maupun kelembagaan. Implikasinya bahwa kehadiran kiai dan Pondok Pesantren HI dapat diterima dengan baik khususnya oleh masyarakat sekitar pesantren maupun secara luas di Kota Palangka Raya.

Multiperan kiai terlihat dari keterlibatannya pada organisasi kemasyarakatan dan organisasi keislaman. Ia merupakan PNS dan sekarang aktif sebagai Ketua Komisi Pemilihan Umum (KPU) Provinsi Kalimantan Tengah, pengurus Forum Kerukunan Umat Beragama (FKUB) Kota Palangka Raya. Selain itu, ia juga aktif sebagai anggota Pengurus Wilayah Nahdlatul Ulama (PWNU) Provinsi Kalimantan Tengah, pengurus Majelis Ulama Indonesia (MUI) Kota Palangka Raya, pengurus Lembaga Pengembangan Tilawatil Qur'an (LPTQ) Kota Palangka Raya dan pengurus Lembaga Seni Qasidah Islam (LASQI) Kota Palangka Raya. Sebagai seorang kiai, maka tugas sebagai administratif leader di pesantren tetap dijalankan di tengah-tengah kesibukan lainnya seperti memberikan ceramah di pengajian-pengajian, sebagai motivator dan dan bahkan mengajar pada perguruan tinggi yang diperankan secara sinergis.

Peran sosial kiai sebagai multiplayer dalam ruang-ruang publik memberikan kesempatan baginya untuk berinteraksi secara lebih luas dengan berbagai kalangan masyarakat terutama masyarakat suku Dayak. Kondisi ini tentu saja sangat membantu kiai dalam beradaptasi bahkan memuluskan jalan bagi terbentuknya integrasi budaya dalam kepemimpinannya di pesantren.

\section{B. Landasan Teori}

Teori yang digunakan dalam penelitian ini adalah kepemimpinan integratif. Huxman \& Vangen (2000:1159) mendefinisikan kepemimpinan integratif sebagai kolaborasi antara individu, proses dan stuktur. Kepemimpinan integratif juga didefinisikan sebagai integrasi dari kemampuan kepemimpinan, sifat, perilaku, 
gaya dan variabel situasional, dalam sebuah model teoritis tunggal untuk dapat menjelaskan efektivitas pemimpin.Definisi lainnya tentang kepemimpinan integratif sebagaimana dikemukakan Wart (2003:214) adalah kepemimpinan yang mengintegrasikan elemen transaksi, transformasi dan variabel situasi yang melekat dalam berbagai kontek masyarakat.Teori lainnya didasarkan pada teori komunikasi E. Mark Hanson (1996:223) yangmengklasifikasi teori-teori komunikasi menjadi teori klasik, teori sistem sosial, dan teori sistem terbuka. Teori klasik telah menetapkan gagasan tentang bagaimana seharusnya proses komunikasi beroperasi, atau siapa seharusnya mengatakan melalui saluran apa, bagi siapa dampaknya. komunikasi digunakan untuk memfasilitasi perintah dan secara vertikal merupakan kendali seorang.

Kajian tentang pesantren dimulai sejak pertengahan abad ke-19 oleh para sarjana Barat seiring dengan kuatnya peran dan pengaruh pesantren dalam kehidupan sosio-kultural, politik dan keagamaan. Beberapa peneliti Barat seperti Brumund, Snouck Hurgronje, Clifford Geertz dan Karel A Steenbrink yang mempelajari Islam di Indonesia secara langsung maupun tidak langsung telah melakukan kajian tentang pondok pesantren (Mardiyah, 2015:31).

Dhofier (2015) dalam penelitiannya tentang tradisi pesantren menjelaskan akar dan sejarah awal berdirinya pesantren, sistem dan metode pengajaran dan penjelasan tentang elemen-elemen pesantren. Ia juga memberi porsi penelitiannya tentang pandangan hidup kiai, termasuk jaringan intelektual dan geneologi kiaikiai di Jawa.Penelitian Mastuhu (1994) tentang dinamika sistem pendidikan pesantren yang menggunakan pendekatan sosiologis-antropologis. HM. Yunus Abu Bakar (2007) yang memfokuskan pada konstruksi pemikiran pendidikan K.H. Imam Zarkasyi dan bagaimana implementasi pemikiran pendidikannya di pondok alumni. Penelitian ini menghasilkan temuan tentang konstruksi pemikiran pendidikan yang dikembangkan oleh K.H. Imam Zarkasyi di Pondok Modern Gontor dan juga menemukan perspektif teoritis model adopsi, yaitu inovasi konstruktif linier (the linear contructive innovation) dan inovasi diversifikasi paralel (the parallel diversified innovation). Terdapat juga tulisan Abd. Halim Soebahar (2013) tentang transformasi kepemimpinan kiai dan sistem pendidikan

Jurnal Darussalam; Jurnal Pendidikan, Komunikasi dan Pemikiran Hukum Islam Vol. XI, No 2:424-448. April 2020. ISSN: 1978-4767 (Cetak), ISSN: 2549-4171(Online) Terakreditasi Nasional. SK. No.36/E/KPT/2019 
pesantren yang meneliti 5 (lima) pondok pesantren di Madura yakni Pesantren Syaikhona Kholil, Pesantren At-Taroqqi, Pesantren Banyuanyar, Pesantren Annuqayah dan Pesantren Al-Amien. Kompetensi seorang pemimpin di pesantren meliputi beberapa aspek, yaitu: kharisma, kualitas keilmuan, kepribadian, kemampuan manajerial dan keikhlasan untuk menerima amanah.

\section{Metode Penelitian}

Penelitian ini menggunakan pendekatan fenomenologis. Penelitian bertempat di Pondok Pesantren Hidayatul Insan Fii Ta'limiddin Kota Palangka Raya yang beralamat di jalan Sulawesi no. 76 Kecamatan Pahandut Kota Palangka Raya Provinsi Kalimantan Tengah. Pengumpulan data menggunakan teknik wawancara, observasi dan dokumentasi. Analisis data dilakukan dengan menggunakan interaktif model melalui melalui tiga alur kegiatan yang terjadi secara bersamaan sebagaimana menurut Miles dan Huberman (1992:16), yakni reduksi data (data reduction), penyajian data (data displays), dan penarikan kesimpulan/verifikasi (conclusion drawing/verifivacation).

\section{Hasil}

\section{Kepemimpinan Pesantren}

Kepemimpinan dalam sebuah organisasi adalah sesuatu yang sangat urgen. Kepemimpinan merupakan spirit untuk menentukan arah pemberdayaan organisasi. Artinya, peran sentral dalam organisasi baik profit maupun non-profit tidak pernah lepas dari kinerja seorang pemimpin untuk menggerakkan potensipotensi yang ada dalam organisasi. Kepemimpinan juga merupakan faktor penentu dalam kesuksesan atau gagalnya suatu organisasi dan usaha. Baik di dunia bisnis maupun di dunia pendidikan, kesehatan, perusahaan, religi, sosial, politik, pemerintahan negara dan lain-lain. Kualitas seorang pemimpin menentukan keberhasilan lembaga atau organisasinya. Pemimpin pula yang menjadi ahli strategi untuk menetapkan tujuan organisasi mengendalikan situasi dan kondisi yang akan berpengaruh terhadap kemajuan dan kemunduran organisasi. Karenanya, tanpa kepemimpinan, organisasi hanya merupakan 
kelompok manusia yang kacau tidak teratur dan tidak akan melahirkan perilaku bertujuan.

Secara umum, kiai sebagai figur sentral dalam komunitas di pesantren memiliki otoritas mutlak untuk menentukan sebuah kebijakan penting. Dalam konteks upaya integrasi budaya Dayak dan pesantren di Pondok Pesantren HI, kiai Harmain adalah komunikator utama yang berupaya memengaruhi bawahannya melalui komunikasi langsung. Ia menekankan pentingnya menghargai kearifan lokal, toleransi dan hidup berbudaya sebagaimana falsafah "di mana bumi di pijak di situ langit dijunjung".

Selain itu, falsafah Pondok Pesantren HI, yakni "di atas dan untuk semua golongan" menurut kiai dapat diartikan sebagai keterbukaan pesantren untuk semua masyarakat muslim dengan tidak memandang suku, etnis, golongan, dan organisasi apapun. Semuanya bisa belajar dan menuntut ilmu di Pondok Pesantren HI. Kendati demikian, penghormatan terhadap budaya lokal tidak boleh diabaikan, bahkan seyogyanya pesantren bisa menjadi bagian dari pelestarian budaya lokal tersebut (Wawancara dengan Kiai Harmain).

Adapun peran komunikator kiai sebagai pengirim atau sumber informasi dilakukan melalui kegiatan-kegiatan berikut.Pertama, rapat-rapat. Kiai merupakan komunikator utama yang memiliki kepentingan komunikasi terhadap anggotanya dalam setiap kegiatan rapat yang dilaksanakan. Komunikasi formal yang dilakukan melalui kegiatan rapat dapat menjadi sarana efektif bagi penyampaian informasi-informasi penting dalam segala hal, termasuk masalah integrasi budaya yang dilaksanakan di Pondok Pesantren HI.Kedua, pengajian kitab. Berbeda dengan pembelajaran di kelas pada umumnya,pengajian kitab kuning atau majelis ta'lim ini dihadiri oleh seluruh santri dengan berbagai tingkatan kelas. Santri wajib menghadiri pengajian rutin yang dilaksanakan, sebagai bagian dari aturan yang sudah ada dalam kegiatan pembelajaran di Pondok Pesantren HI Kota Palangka Raya. Dalam kegiatan ini tidak ada proses tanya jawab berlangsung, para santri bersifat pasif dan hanya mendengarkan apa yang disampaikan oleh kiai. Adapun materi yang disampaikan oleh kiai dalam pengajian kitab kuning ini, sebenarnya tidak melulu mengenai kitab itu sendiri, namun dalam kesempatan ini, 
tidak jarang kiai juga memberikan arahan mengenai kegiatan sehari hari terkait proses pembelajaran yang berlangsung di pondok pesantren, menyampaikan informasi, peraturan, pengumuman juga anjuran agar kegiatan pembelajaran dengan baik dan maksimal (Wawancara dengan Kiai Harmain).Penelusuran penulis selama observasi lapangan, di Pondok Pesantren HI terdapat 3 pengajian kitab kuning. Salah satunya adalah pengajian Tauhid yang diasuh langsung oleh kiai pada subuh Minggu (Observasi).

Dari informasi di atas, pada dasarnya majelis ta'lim yang dilaksanakan sebagai rutinitas di Pondok Pesantren HI ini adalah bagian dari sarana untuk memberikan informasi secara menyeluruh baik itu perihal keagamaan, pendidikan dan hal-hal penting lainnya. Apabila ada informasi terkait pengumuman penting, misalnya mengenai jadwal libur pondok, informasi mengenai perlombaan, peraturan baru, ataupun arahan yang ditujukan untuk santri secara menyeluruh, maka kiai bisa menggunakan kesempatan ini untuk menyampaikan secara langsung pada akhir pengajian. Sehingga seluruh santri dapat mengetahui informasi tersebut langsung dari kiai. Meski demikian, hal-hal yang berhubungan dengan teknis secara lebih detail diumumkan lebih lanjut oleh pengurus yang berwenang. Ketiga, pembelajaran di kelas. Proses komunikasi dalam pembelajaran di kelas melibatkan kiai dan santri dengan tatap muka langsung. Hal yang membedakan dengan majelis ta'lim atau pengajian kitab kuning adalah proses komunikasi berlangsung dalam skala kelompok yang lebih kecil, yaitu hanya santri-santri yang terdapat dalam satu kelas tersebut.

Observasi penulis ketika kiai mengajar pelajaran Nahu (kitab Kawâkib alDhurriyah), terlihat kiai menjelaskan materi dan para santri mendengarkan pengarahan dengan seksama.Pada sekali waktu murid memberikan pertanyaan, menanggapi ataupun menjawab pertanyaan langsung yang diajukan padanya. Ketika ada materi yang belum dipahami oleh santri tersebut, maka kiai akan memberikan penjelasan secara seksama, hingga terjadinya proses tanya jawab yang memudahkan santri sebagai murid memahami penjelasan yang diberikan oleh kiai (Observasi). 
Kiai sebagai leader di pesantren memiliki tanggung jawab besar terhadap semua unsur organisasi pesantren, termasuk upaya mengembangkan budaya pesantren yang berkemajuan. Komitmen merupakan faktor penting yang meneguhkan kiai dan orang yang dipimpin dalam pesantren menjalani tanggung jawab kepemimpinan yang diembannya. Sebagai "tamu" yang hadir di tengahtengah komunitas masyarakat Dayak Palangka Raya, kiai mampu beradaptasi dengan budaya masyarakat setempat, mau mengenal budaya orang lain dan berusaha untuk bisa beradaptasi secara cepat. Hal ini sebagaimana yang dikemukakan Kiai Harmain: "Sebagai warga pendatang sudah sewajarnya kita menghormati budaya masyarakat di sini, kaya jar papatah (sebagaimana pepatah) "di mana bumi dipijak disitu langit dijunjung". Terlebih lagi orang Dayak tu baisi budaya huma betang, belom bahadat dan mereka sangat menghargai kita-kita warga pendatang...amun kita kada menghargai buhannya dan kada bisa bersikap ramah, bisa diusirnya kita dari kampungnya. (terlebih lagi orang Dayak itu memiliki budaya "huma betang", "belom bahadat" dan mereka sangat menghargai warga pendatang...kalau tidak bisa menghargai budaya mereka, maka mereka bisa mengusir kita).

Meskipun tidak mempelajari budaya Dayak secara khusus dan mendalam, tetapi karena pergaulan kiai yang cukup luas dengan masyarakat berbagai lapisan di Kota Palangka Raya, juga perannya yang aktif di berbagai organisasi kemasyarakatan, maka tidak mengherankan bila kiai banyak mengenal budaya Dayak dan cepat beradaptasi dengan budaya tersebut. Sikap kiai yang mau mengenal dan mempelajari budaya Dayak adalah bagian dari klarifikasi potensi diri. Hidup dan bertahan di suatu komunitas yang bukan menjadi komunitasnya sebagai newcomer membutuhkan adaptasi yang cepat. Karena kalau tidak demikian, maka dapat dipastikan tidak akan mampu bertahan.

Dalam pergaulan masyarakat, kiai Harmain dikenal dengan sosok pribadinya yang kharismatik, humanis, toleran, mudah bergaul dengan siapa saja dan baik budi pekertinya. Hal ini sebagaimana pengamatan selama penelitian dan juga berdasarkan pandangan-pandangan masyarakat sebagai berikut. "Meskipun kiai Harmain orang asli Banjar, tetapi beliau bisa bahasa Dayak. Beliau orangnya 
toleran dan menghargai budaya Dayak. Kalau ketemu biasanya beliau menyapa kami dengan bahasa Dayak. Kami yang lama bertetangga cukup mengenal pribadi beliau yang sopan, baik akhlaknya dan sangat terbuka dengan siapa saja, pokoknya memasyarakat lah" (wawancara dengan masyarakat). Pendapat lainnya disampaikan Fahmi, salah seorang warga yang relatif lama tinggal di lingkungan Pondok Pesantren HI. Menurutnya kiai Harmain adalah sosok yang santun, baik budi pekertinya dan suka menolong. Meskipun pergaulannya luas dari berbagai kalangan, tetapi ia tidak sombong dan mau bergaul dengan siapa saja. Kiai Harmain sering mengundang warga sekitar jika di pesantren ada hajatan atau acara.

Sikap kepemimpinan lainnya pada diri kiai adalah adanya keselarasan tindakan dengan nilai-nilai bersama. Selain klarifikasi nilai-nilai dan potensi diri, aspek penting dari keteladanan adalah keselarasan tindakan dengan nilai-nilai bersama yang sudah disepakati. Di antara keteladanan kiai dalam konteks integrasi budaya Dayak dan pesantren adalah bersedia memakai baju corak khas Dayak Kalteng, mau menggunakan bahasa Dayak dalam komunikasi tertentu, menjadikan ornamen Dayak sebagai bagian dari ornamen pesantren dan rumah.

\section{Integrasi Budaya dalam Kepemimpinan Kiai di Pesantren}

Pondok Pesantren Hidayatul Insan Fii Ta'Limiddin Kota Palangka Raya (yang selanjutnya disebut Pondok Pesantren HI) merupakan sebuah institusi pendidikan Islam yang hadir di tengah-tengah masyarakat plural di Kota Palangka Raya. Pondok pesantren yang berdiri sejak tahun 1987 ini masih tetap survive dan bahkan menjadi pesantren "terbesar" yang ada di Kota Palangka Raya. Keberadaaan Pondok Pesantren HI Palangka Raya selama kurang lebih tiga dekade, telah memainkan peranan strategis sebagai agent of change bagi proses kaderisasi keislaman di Kota Palangka Raya. Pondok pesantren ini juga mampu eksis dan bersaing prestasinya dengan sekolah-sekolah unggulan di Kota Palangka Raya baik secara akademik maupun non akademik.

KH. Harmain Ibrahim selaku kiai pada Pondok Pesantren HI adalah salah satu tokoh muda yang sangat dikenal di Kalimantan Tengah khususnya di Kota Palangka Raya. Hal ini tidak terlepas dari perannya bagi masyarakat Kota 
Palangka Raya baik dalam bidang dakwah, pendidikan, politik dan kemasyarakatan. Sebagai warga pendatang, Kiai Harmain telah melakukan proses adaptasi terhadap budaya lokal baik secara personal maupun secara kelembagaan. Hal ini dilakukan agar kehadiran pesantren di tengah masyarakat Dayak dapat diterima dengan baik.

Kehadiran pondok pesantren di tengah-tengah masyarakat Suku Dayak memerlukan proses adaptasi yang kuat. Di antara proses adaptasi tersebut adalah :

1. Lokasi

Pesantren HI lokasinya berada di pinggiran sungai Kahayan dengan bangunan asrama santri dan tempat belajar nampak tidak tertata dengan rapi dan masih berupa bangunan dari kayu. Area pondok pesantren ini menyatu dengan pemukiman penduduk yang memiliki kultur beragam, bahkan tidak ada pembatas yang memisahkan area pondok pesantren dari lingkungan masyarakat. Berdasarkan hasil observasi, sampai sekarang area pondok pesantren masih berbaur dengan lingkungan masyarakat setempat tanpa sekat dan batas-batas tertentu kecuali bangunan-bangunan milik pesantren. Tidak jauh dari area pondok pesantren masih terdapat simbol-simbol keagamaan non Islam seperti gereja dan sandungyaitu tempat menyimpan tulang orang yang sudah meninggal setelah upacara Tiwah bagi masyarakat Dayak yang beragama Kaharigan/Hindu Kaharingan,bahkan masih terlihat dengan jelas dari pondok pesantren adanya area kandang babi di permukiman masyarakat setempat.

Secara historis (terutama di Kalimantan Tengah), masyarakat Suku Dayak adalah komunitas masyarakat yang banyak tinggal di pinggiran sungai/DAS (Daerah Aliran Sungai), karena sungai merupakan sarana dan akses yang dianggap efektif bagi mereka, baik untuk mandi, mencuci dan lain-lain. Keberadaan pesantren HI yang letaknya di pinggir sungai secara filosofis juga bagian dari integrasi dan adaptasi terhadap budaya dan kebiasaan masyarakat lokal. Pada saat-saat tertentu para santri juga mandi di sungai dan dapat berinteraksi dengan masyarakat setempat. 
Meskipun pesantren telah memiliki lahan yang strategis di dataran tinggi di tengah kota, tetapi menurut Kiai, sementara ini ia akan tetap memilih dan mempertahankan pesantren HI tetap berada di lokasi lama meskipun tempatnya nampak kurang kondusif karena harus berbaur dengan pemukiman masyarakat. Argumentasi kiai adalah bahwa pesantren HI telah eksis lebih dari 30 tahun di tempatnya sekarang, dukungan masyarakat sekitar terhadap keberadaan pesantren sangat baik, serta perlunya para santri memiliki peran ganda, yaitu sebagai santri yang sedang belajar sekaligus sebagai anggota masyarakat. Berbaur dengan masyarakat akan menjadikan santri lebih mengerti kehidupan yang sesungguhnya, paham artinya perbedaan untuk saling menghargai dan toleransi.

2. Bahasa

Bahasa adalah elemen yang sangat penting dalam proses sosialisasi dan interaksi antarsesama. Adanya perbedaan bahasa dan ketidakmampuan berbahasa dapat menimbulkan mispersepsi yang dapat berujung pada kesalahpahaman hingga konflik. Dalam upaya mengatasi perbedaan bahasa, kiai secara otodidak berusaha mempelajari dan menggunakan bahasa Dayak Ngaju yang banyak digunakan oleh mayoritas masyarakat Suku Dayak di Kota Palangka Raya. Kemampuan kiai menggunakan bahasa Dayak sebagai bahasa masyarakat setempat sangat membantu dalam proses interaksi personal maupun kelembagaan. Implikasinya bahwa kehadiran kiai dan pesantren HI dapat diterima dengan baik khususnya oleh masyarakat sekitar pesantren maupun secara luas di Kota Palangka Raya.

3. Pakaian

Keunikan lainnya dalam pribadi kiai adalah dari sisi cara berpakaian. Dalam konteks adaptasi budaya, kiai sering dan terbiasa menggunakan pakaian batik khas corak kalimantan tengah, terutama dalam kegiatankegiatan formal di luar pesantren.

4. Peran Sosial

Kiai selain sebagai pimpinan pesantren, juga memainkan peranan penting pada bidang sosial lainnya. Di bidang dakwah dan keagamaan ia 
adalah sosok da'i yang cukup diperhitungkan karena sering diundang untuk memberi tausiyah pada peringatan hari besar Islam seperti peringatan maulid Nabi Muhammad SAW, isra mi'raj dan hari-hari besar Islam lainnya baik di sekolah-sekolah, mesjid, instansi pemerintah dan juga di rumahrumah penduduk. Selain itu juga rutin menjadi khatib hari Jum'at dan pada hari raya Idul Fitri dan Idul Adha. Peran lainnya ia tunjukkan dengan berpartisipasi aktif di berbagai organisasi keagamaan Islam di Kota Palangka Raya. Ia aktif sebagai pengurus Majelis Ulama Indonesia (MUI) Kota Palangka Raya periode 2009-2014 dan 2014-2019 sebagai Ketua Komisi Dakwah. Ia juga aktif di organisasi Badan Koordinasi Pemuda Remaja Masjid Indonesia Kota Palangka Raya (BKPRMI) selama dua periode dari tahun 2009 hingga sekarang. Tiga periode aktif di Lembaga Pengembangan Tilawatil Qur'an (LPTQ) Kota Palangka Raya pada bagian pembinaan (2005 s.d 2019). Anggota Dewan Masjid Indonesia Kota Palangaka Raya (2014-2019) dan menjadi wakil ketua pada organisasi Lembaga Seni Qosidah Indonesia (LASQI) selama tiga periode (2007 sd 2018).

Kiprahnya pada bidang pendidikan selain mengelola pesantren juga menjadi dosen di perguruan tinggi Islam yang ada di Kalimantan Tengah serta menjadi motivator pada beberapa event kegiatan kemahasiswaan dan kegiatan siswa di sekolah. Di bidang kemasyarakatan, ia juga aktif sebagai pengurus beberapa organisasi kemasyarakatan di Kota Palangka Raya seperti anggota aktif Forum Kerukunan Umat Beragama Kota Palangka Raya dan anggota Pengurus Wilayah Nahdlatul Ulama Provinsi Kalimantan Tengah. Selain itu ia juga sebagai salah satu anggota Komisi Pemilihan Umum Daerah (KPUD) Kota Palangka Raya sebagai wujud nyata peran aktif kiai dalam kancah politik.

Peran sosial kiai sebagai multiplayer dalam ruang-ruang publik memberikan kesempatan baginya untuk berinteraksi secara lebih luas dengan berbagai kalangan masyarakat terutama masyarakat suku Dayak. Kondisi ini tentu saja sangat membantu kiai dalam beradaptasi bahkan 
memuluskan jalan bagi terbentuknya integrasi budaya dalam kepemimpinannya di pesantren.

Komitmen kiai terhadap berlangsungnya integrasi budaya pesantren dan budaya Dayak di lembaga yang ia pimpin direalisasikan pada beberapa aspek, antara lain:

a. Memasukkan mata pelajaran bahasa Dayak sebagai bagian dari kurikulum yang digunakan yaitu pada mata pelajaran muatan lokal. Hal ini sekaligus menyahuti program pemerintah daerah dalam konteks pelestarian bahasa daerah yang menganjurkan agar bahasa Dayak dijadikan alternatif pada pelajaran muatan lokal di sekolah.

b. Menjadikan seni tari Dayak sebagai kegiatan ekstra kurikuler. Seni tari Dayak dengan berbagai kreasinya sering digunakan pada kegiatan ritual pesantren seperti hari ulang tahun pesantren, pelepasan dan perpisahan santri, dan kegiatan lainnya.Kegiatan ekstra kurikuler ini dengan mengkolaborasikan budaya seni tari Dayak yang bernuansa islami bahkan telah membawa harum nama Pondok Pesantren HI di kancah nasional dengan meraih Juara II Tingkat Nasional Lomba Kesenian Daerah bernuansa Islami yang dilaksanakan di Makasar pada bulan Agustus 2017.

c. Dalam rangka ikut memasyarakatkan budaya lokal sebagai bagian dari proses integrasi budaya Dayak dan budaya pesantren, santri-santri diwajibkan memakai pakaian batik khas corak Kalimantan Tengah sebagai pakaian resmi yang digunakan dalam proses belajar mengajar di kelas, yaitu satu hari dalam seminggu, pada hari Rabu.

d. Penggunaan ornamen-ornamen khas Dayak dalam penataan lingkungan pondok pesantren, seperti pintu gerbang, kaligrafi yang dipasang di kelas dan lain-lain.

e. Penggunaan bahasa Dayak dalam berinteraksi dan bersosialisasi di lingkungan pondok pesantren baik yang dilakukan kiai, para ustadz maupun santri. 
f. Membangun kerjasama dengan lembaga masyarakat adat Dayak seperti Lembaga Literasi Dayak, Sanggar Tari dan Dewan Adat Dayak.

\section{E. Pembahasan}

\section{Kepemimpinan Pesantren}

Pada hakikatnya kepemimpinan kiai di pesantren merupakan kepemimpinan yang berkepribadian dan memiliki ciri utama kekharismatikan. Watak kharismatik kiai bisa disebabkan kemumpuniannya atau kemampuan sang kiai, serta pengaruhnya yang tidak hanya dinilai masyarakat dari segi keilmuan saja, melainkan juga nilai dari kewibawaan yang bersumber dari kedalaman ilmu agama juga faktor keturunan.

Eksistensi seorang kiai sebagai pemimpin pesantren, ditinjau dari tugas dan fungsinya dapat dipandang sebagai fenomena kepemimpinan yang unik. Dikatakan unik, kiai sebagai pemimpin pondok pesantren tidak sekedar bertugas menyusun kurikulum, membuat peraturan tata tertib, merancang sistem evaluasi, tetapi juga sekaligus melaksanakan proses belajar mengajar yang berkaitan dengan ilmu-ilmu agama di lembaga yang diasuhnya. Selain itu, ia bertugas pula sebagai pembina dan pendidik umat serta menjadi pemimpin masyarakat (Arifin, 1993:45).Terkait dengan tugas dan fungsi sebagai pemimpin, kiai harus memiliki integritas terhadap kebenaran, kejujuran dan keadilan agar dapat dipercaya. Selain itu, kiai harus menguasai informasi, keahlian profesional dan kekuatan moral agar ia ditaati, serta memiliki pesona pribadi yang tidak saja menjadikan seorang kiai dicintai dan dijadikan panutan melainkan dijadikan pula figur keteladanan dan sumber inspirasi bagi komunitas yang dipimpinnya (Nasir, 2010:304).

Adapun sifat-sifat kepemimpinan kiai secara substansi seharusnya merujuk pada sifat-sifat kepemimpinan dalam Islam sebagaimana Nabi Muhammad SAW yang memiliki sifat siddîq, amãnah, tablîgh dan fathõnah. Sifat siddîq yang berarti memiliki perilaku yang benar dan jujur, benar dalam mengambil keputusan yang menyangkut visi, misi dan program serta efektif dan efisien dalam pelaksanaannnya. Sifat amõnah yang berarti dapat dipercaya, bertanggung jawab 
dan kredibel. Sifat tablîgh yang berarti menyampaikan dengan benar dengan caracara yang tepat, komunikatif dan argumentatif. Sifat fathõnah yang berarti cerdas dan bijaksana serta memiliki pemikiran yang dapat menumbuhkan kreativitas dan inovasi-inovasi.

Sejalan dengan keterangan di atas, menurut Permadi (1996:65) pada dasarnya seorang pemimpin haruslah memiliki bobot kepemimpinan dengan sifat-sifat positif dan kelebihan-kelebihan tertentu, antara lain beriman dan bertakwa, kelebihan jasmani dan kelebihan batin, berani, terampil, berpengetahuan, adil, jujur, bijaksana, demokratis, penyantun, paham keadaan umat, ikhlas dan rela berkurban, qana'ah serta istiqomah.Sifat-sifat kepemimpinan yang disebutkan memang tidaklah mungkin dimiliki secara sempurna oleh seorang kiai. Selalu ada kelebihan di satu sisi dan kekurangan atau kekurangsempurnaan di sisi lainnya. Namun demikian, pengetahuan dan pemahaman terhadap sifat-sifat kepemimpinan ideal akan menjadikan seseorang berusaha untuk selalu meningkatkan kualitas kepemimpinannya dan meminimalisir segala kekurangan yang ada pada dirinya.

Kepemimpinan integratif kiai di Pondok Pesantren HI ditunjukkan dengan pola komunikasi dan komitmen kepemimpinan yang sangat menghargai local wisdom dan upayanya mengintegrasikan budaya Dayak ke dalam budaya pesantren. Upaya ini dalam rangka kebertahanan pesantren di tengah masyarakat suku Dayak yang memiliki adat istiadat yang sangat ketat. Hal ini sejalan dengan konteks kepemimpinan integratif sebagaimana dikemukakan Wart (2003 : 214) sebagai kepemimpinan yang mengintegrasikan elemen transaksi, transformasi dan variabel situasi yang melekat dalam berbagai kontek masyarakat. Kepemimpinan integratif adalah model kepemimpinan koperatif, kepemimpinan demokratis yang mengintegrasikan semua pemangku kepentingan, tujuan dan peranan yang berbeda, integrasi dari orang, tujuan, struktur, peran setiap anggota organisasi sesuai situasi dan kondisi untuk mencapai efektivitas organisasi. Kerangka model kepemimpinan integratif dapat mengintegrasikan banyak variabel, seperti kemampuan, perilaku, sikap, gaya kepemimpinan dan lain-lain. 
Kepemimpinan integratif kiai di pesantren sebagaimana hasil penelitian di atas setidaknya dipengaruhi oleh empat faktor yang melatarbelakanginya. Pertama, faktor keluarga yang langsung maupun tidak langsung telah melekat pada dirinya. Kedua, faktor latar belakang pendidikan yang sangat berpengaruh dalam pola pikir, sikap dan tingkah lakunya. Ketiga, pengalaman yang memengaruhi kebijaksanaan dalam tindakannya. Keempat, lingkungan masyarakat sekitar yang akan menentukan arah yang harus diperankannya (Mardiyah, 2015:67).

Dari uraian di atas tergambar bahwa kepemimpinan kiai di pondok pesantren memiliki corak dan gaya yang beragam sesuai dengan ruang dan waktu di mana kiai itu berada serta berbagai faktor yang mempengaruhinya. Selain itu, sifat-sifat kepemimpinan kiai di pondok pesantren secara substansi merefleksikan sifat-sifat kepemimpinan yang pernah diimplementasikan oleh Nabi Muhammad SAW.

Kepemimpinan kiai dalam mengintegrasikan budaya pesantren dan budaya Dayak di pesantren tidak terlepas dari pandangan visioner kiai tentang eksistensi dan tantangan dunia pesantren di era globalisasi dewasa ini. Di sisi lain, perlunya model pesantren yang menghargai local wisdom demi kebertahanan pesantren di tengah masyarakat suku Dayak yang memiliki tradisi dan adat istiadat. Upaya perubahan terhadap pola pesantren dengan melakukan integrasi budaya tersebut dimulai dengan memahami konteks budaya Dayak, proses eksternalisasi dan adaptasi, hingga strategi dalam menginternalisasi nilai, norma, attitude budaya dayak di pondok pesantren. Upaya-upaya yang dilakukan di antaranya melalui pola komunikasi sistem klasik dalam menunjang integrasi budaya yang diharapkan. Hal ini sejalan dengan teori komunikasi sistem klasik E. Mark Hanson (1996:223) sebagai komunikasi yang digunakan untuk memfasilitasi perintah dan secara vertikal merupakan kendali seorang saja (kiai). Orentasi teori klasik menggambarkan bahwa komunikasi merupakan pengiriman informasi yangcenderung bersifat top-down, membawa pesan dari satu orang ke orang lain (Hanson, 1996:222). Di antara kelebihan pola ini adalah bahwa kiai lebih fokus pada rencana saat membuat kebijakan, perintah dan arahan. Komunikasi juga bersifat formal dan dapat terhindar dari overload karena kesalahan dalam proses 
informasi. Hal ini sejalan dengan pandangan Rogers (1976:34) yang menyatakan bahwa komunikasi klasik menjadi formal, hierarki dan terencana. Tujuannya untuk mempermudah pekerjaan yang dilakukan dan meningkatkan efisiensi dan produktifitas.

Dari deskripsi yang telah dikemukakan tersebut, tampak kepemimpinan kiai sebagai pimpinan Pondok Pesantren HI mampu memelihara budaya keberagamaan di tengah keberagaman budaya masyarakat. Kiai berupaya merekonsiliasi agama dengan budaya masyarakat setempat, sehingga memunculkan kepemimpinan yang menghargai adat istiadat, kebudayaan dan filosofi suku Dayak, kepemimpinan yang menjunjung tinggi nilai-nilai kemanusiaan, hak asasi, pluralisme dan toleransi yang kemudian diintegrasikan dengan budaya pesantren. Dimensi kepemimpinan seorang kiai di Pondok Pesantren HI sangatlah kompleks. Ia berperan sebagai community leader (pemimpin masyarakat) manakala tampil sebagai pemimpin organisasi masyarakat atau organisasi politik, intellectual leader (pemimpin keilmuan) dalam kapasitasnya sebagai guru agama, dosen danmotivator, spiritual leader (pemimpin kerohanian) ketika ia menjadi pemimpin peribadatan, menjadi mursyid thariqah serta panutan moral masyarakat, dan administratif leader (pemimpin administratif) saat ia berperan sebagai pimpinan Pondok Pesantren. Sebagai seorang kiai, tugas sebagai administratif leader di pesantren tetap dijalankan di tengah-tengah kesibukan lainnya seperti memberikan ceramah di pengajianpengajian, sebagai motivator dan dan bahkan mengajar pada perguruan tinggi yang diperankannya secara sinergis.

\section{Integrasi Budaya dalam Kepemimpinan Kiai di Pesantren}

Bentuk-bentuk integrasi budaya Dayak dan budaya pesantren meliputi letak posisi pesantren yang masih menyatu dengan permukiman penduduk masyarakat Dayak. Pola pikir kiai agak berbeda dengan kebanyakan pendapat tentang efektivitas letak suatu lembaga pendidikan termasuk pesantren. Sebagaimana pendapat Karel A. Steenbrink (1974:15) yang menyatakan bahwa pada umumnya pesantren terletak di pinggiran kota atau di desa yang agak jauh dari kota. Ia merupakan satu lingkungan yang khusus dan terpisah dari pemukiman 
lainnyaRealitasnya hampir semua pesantren selalu memiliki tempat yang terpisah dengan lingkungan masyarakat sehingga terkesan ekslusif. Berbeda dengan Pesantren HI, kondisi ini menjadikan Pondok Pesantren HI sebagai lembaga pendidikan Islam yang inklusif. Di sisi lain, di tengah-tengah iklim sosial budaya yang multikultural dan terkesan kurang kondusif, pondok pesantren ini dapat menjalankan aktivitas pembelajaran dengan baik, kegiatan-kegiatan ekstra kurikuler seperti olah raga, kesenian, pramuka dan lain-lain berjalan sebagaimana adanya.

Berdasarkan paparan data dan temuan penelitian tentang integrasi budaya maka dapat disampaikan bahwa dalam konteks ini kiai mampu menjadi teladan bagi semua warga Pondok Pesantren HI. Hal ini tercermin dari sikap dan tindakannya yang elegan dengan kemampuannya mengklarifikasi nilai dan potensi diri serta berusaha menyelaraskan tindakan dengan nilai-nilai bersama yang telah dibangun dan disepakati.

Kiai menyadari eksistensi dirinya sebagai "tamu" di tengah masyarakat suku Dayak, sehingga mau tidak mau harus mampu beradaptasi dengan cepat terhadap lingkungan sosial budaya dan membangun relationship yang baik dengan budayabudaya yang ada di sekitarnya, terutama budaya masyarakat Dayak. Sensitivitas kiai dalam melihat nilai-nilai budaya lokal serta progresivitas dalam berinteraksi menjadi sangat diperlukan untuk harmonisasi dan kebertahanan Pondok Pesantren HI. Sebab jika tidak, maka kecil kemungkinan pondok pesantren ini akan mampu survive hingga lebih dari tiga dekade. Hal ini sebagaimana yang dikemukakan Vianen (2000:13) bahwa new comer (pendatang baru) yang memiliki perbedaan persepsi terhadap budaya (organisasi) yang berhubungan dengan komitmen dan tujuan organisasi, tidak akan mampu bertahan di organisasi tersebut.

Dalam upaya mengatasi perbedaan bahasa, kiai secara otodidak berusaha mempelajari dan menggunakan bahasa Dayak Ngaju yang banyak digunakan oleh mayoritas masyarakat Suku Dayak di Kota Palangka Raya. Kemampuan kiai menggunakan bahasa Dayak sebagai bahasa masyarakat setempat sangat membantu dalam proses interaksi personal maupun kelembagaan. Implikasinya bahwa kehadiran kiai dan Pondok Pesantren HI dapat diterima dengan baik 
khususnya oleh masyarakat sekitar pesantren maupun secara luas di Kota Palangka Raya. Dengan memahami bahasa Dayak, kiai mampu berinteraksi secara lebih luas dan berperan aktif di luar pesantren. Sebagai elemen yang sangat penting dalam proses sosialisasi dan interaksi antarsesama, maka bahasa suatu masyarakat harus pelajari dengan baik Adanya perbedaan bahasa dan ketidakmampuan berbahasa yang disepakati dapat menimbulkan mispersepsi yang bahkan bisa berujung pada konflik. Hal ini sejalan dengan petunjuk al-Qur'an yang menyatakan bahwa seorang penyampai risalah (Rasul) tidak diutus kecuali dengan menggunakan bahasa kaumnya sendiri agar ia dapat menjelaskan risalah tersebut kepada mereka (QS. Ibrahim/14:14).

Pribadi kiai yang dikenal masyarakat Palangka Raya terutama warga masyarakat sekitar pondok pesantren sebagai sosok yang santun, inklusif dan menghargai kearifan lokal menunjukkan adanya komitmen bagi terwujudnya integrasi budaya, budaya masyarakat Dayak di satu sisi dan budaya pesantren di sisi lainnya. Menjadi sebuah keharusan bila seorang kiai sebagai pemimpin pondok pesantren memiliki sifat-sifat yang baik, karena ia adalah sosok panutan dalam lingkungan pesantren yang dipimpinnya bahkan bagi masyarakat secara luas. Tetapi menjadi sangat spesial manakala seorang kiai mau mengenal dan mempelajari budaya orang lain dan berusaha mencari titik temu antarbudaya untuk diintegrasikan dan dijadikan budaya baru dalam pondok pesantren. Dengan sifat-sifat mahmudah-nya sebagaimana disebutkan kiai telah membuka ruang bagi terciptanya integrasi antarbudaya tersebut secara berkelanjutan.

Dalam hal berpakaian, kiai tidak selalu memakai pakaian "kebesaran"nya sebagaimana yang biasa dipakai seorang kiai- menggunakan jubah dan sorban atau imamah, tetapi juga mau menggunakan pakaian batik khas Dayak Kalimantan Tengah (bahkan terkadang lengkap dengan saung) dalam kesehariannya. Menurut penulis, ada dua alasan utama mengapa kiai mau menanggalkan identitas pakaian ke-kiai-annya dan memakai pakaian batik khas Dayak. Pertama, untuk memberi contoh kepada semua warga pondok pesantren, karena sebagaimana disebutkan dalam hasil penelitian bahwa salah satu budaya Pondok Pesantren HI adalah penggunaan pakaian batik khas Dayak Kalimantan 
Tengah pada hari tertentu bagi seluruh warga pondok pesantren. Kedua, terkait dengan peran aktif kiai di luar pesantren terutama jabatannya sebagai ketua KPU Provinsi Kalimantan Tengah. Alasan kedua menjadi sangat dominan mengingat aktivitas kiai di KPU secara etis mengharuskannya sering memakai pakaian formal dan juga batik. Namun demikian, secara esensial keteladanan dalam pelaksanaan nilai-nilai budaya integratif tetap melekat dalam diri kiai.

Sebagai wujud komitmen kiai dalam integrasi budaya Dayak Pesantren dalam konteks keteladanan, maka ia juga secara sukarela dengan batasan kemampuan yang dimilikinya berusaha menggunakan bahasa Dayak Ngaju yang biasa digunakan masyarakat Dayak Palangka Raya. Meskipun tidak sempurna ucapan dan gaya bahasanya dan terkadang bercampur-campur dengan bahasa Banjar atau bahasa Indonesia, tetapi hal itu tetap dilakukan. Urgensi berbahasa Dayak yang dilakukan kiai adalah untuk mendekatkan diri dengan budaya masyarakat setempat, juga untuk kemudahan bersosialisasi dan berkomunikasi mengingat bahwa bahasa Dayak adalah bahasa yang paling sering digunakan oleh masyarakat Kota Palangka Raya. Bahasa Dayak Ngaju sebagai salah satu bahasa asli daerah Kalimantan Tengah digunakan masyarakat dalam bersosialisasi dan berkomunikasi hampir di seluruh aspek kehidupan masyarakat. Bahasa ini digunakan oleh masyarakat Dayak maupun non-Dayak dalam percakapan seharisehari seperti di pasar, sekolah-sekolah bahkan di lembaga pemerintahan.Bentuk integrasi lainnya yang ditunjukkan kiai bagi warga pesantren $\mathrm{HI}$ dalam menginternalisasi nilai-nilai budaya Dayak pesantren adalah kesediaannya menggunakan ornamen-ornamen bernuansa Dayak sebagai hiasan di rumahnya.

Tindakan kiai dengan mau menanggalkan identitas pakaian ke-kiai-annya dan menggunakan pakaian batik khas Dayak Kalimantan Tengah, berkomunikasi dengan menggunakan bahasa Dayak, menggunakan ornamen bernuansa Dayak dan tinggal di permukiman padat penduduk -yang banyak tinggal di sekitarnya masyarakat Dayak setidaknya telah menjadi contoh yang baik bagi terwujudnya integrasi budaya Dayak dan budaya pesantren. Kiai mampu menjadi role model utama pelaksanaan nilai-nilai integratif tersebut di Pondok Pesantren HI. Keselarasan tindakan kiai dengan nilai-nilai integratif yang telah disepakati

Jurnal Darussalam; Jurnal Pendidikan, Komunikasi dan Pemikiran Hukum Islam Vol. XI, No 2:424-448. April 2020. ISSN: 1978-4767 (Cetak), ISSN: 2549-4171(Online) Terakreditasi Nasional. SK. No.36/E/KPT/2019 
merupakan cerminan komitmen kepemimpinan yang kuat, yang memang seyogyanya ada dalam kepemimpinan pesantren. Hal ini sebagaimana yang tersirat dalam al-Qur'an surah As Shaff ayat 2 dan 3 berikut.

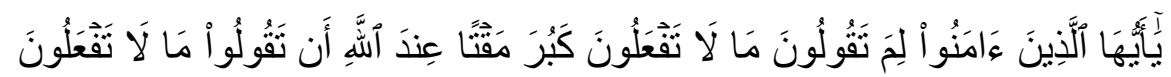

Artinya: Wahai orang-orang yang beriman, kenapakah kamu mengatakan sesuatu yang tidak kamu kerjakan? Amat besar kebencian di sisi Allah bahwa kamu mengatakan apa-apa yang tidak kamu kerjakan.

Ayat ini secara absolut mengecam orang yang mengatakan sesuatu, namun dia tidak melakukannya, apapun itu bentuknya. Maka keberadaan kiai sebagai pemimpin pesantren dalam tugas dan fungsinya wajib menjadi suri teladan bagi semua warga pesantren dengan menyelaraskan tindakan dengan ucapan dan kebijakan serta nilai-nilai bersama yang telah disepakati.

\section{F. Kesimpulan}

Secara umum kepemimpinan pesantren merupakan fenomena kepemimpinan yang cenderung autocracy, di mana kekuasaan dan kewenangan tertinggi ada di tangan kiai. Kepemimpinan integratif sebagai model kepemimpinan yang koperatif, kepemimpinan demokratis yang dapat mengintegrasikan banyak variabel, seperti kemampuan, perilaku, sikap, gaya kepemimpinan dapat menjadi alternatif model kepemimpinan terutama dalam konteks integrasi budaya di pondok pesantren.

Kepemimpinan integratif dalam konteks integrasi budaya pesantren dan budaya lokal dapat dilakukan melalui proses adaptasi kawasan, bahasa, pakaian dan peran sosial kiai di masyarakat. Proses integrasi dimulai dengan memahami konteks budaya lokal, proses eksternalisasi dan adaptasi, hingga strategi dalam menginternalisasi nilai, norma, attitude budaya Dayak di pondok pesantren. 


\section{Daftar Pustaka}

Abu Bakar, HM, Yunus. 2007. Konsep Pemikiran Pendidikan K.H. Imam Zarkasyi dan Implementasinya pada Pondok Pesantren Alumni. Disertasi. Yogyakarta: Program Pascasarjana UIN Sunan Kalijaga.

Arifin, I.1993.Kepemimpinan Kiai: Kasus Pondok Pesantren Tebuireng. Malang: Kalimasahada Press.

Bruinessen, MV. 2015. Kitab Kuning, Pesantren dan Tarekat. Yogyakarta: Gading Publishing.

Dhofier, Zamakhsyari. 2015. Tradisi Pesantren, Studi Pandangan Hidup Kyai dan Visinya Mengenai Masa Depan Indonesia. Jakarta: LP3ES.

Siti Aimah, Lely Ana Ferawati Ekaningsih. 2017. Tipe Kepemimpinan Ny. Hj. Dra. Mahmudah Hisyam dalam Memimpin Asrama Roudlotul Qur'an Pesantren Darussalam Putri Blokagung. Jurnal Darussalam: Jurnal Pendidikan, Komunikasi dan Pemikiran Hukum Islam. Vol. VIII, No 2 April

Geertz, C..1960. "The Javaanese Kijaji: the Changing Roles of a Cultural Broker". Comparative Studies in Society and History, Vol. 2 No. 2 Januari 1960.

Hanson, E Mark. 1996. Educational Administration and Organizational Behavior. USA: A Simon \& Schuster Company.

Hughes, G and Curphy. 2002. Leadership: Enhanching The Lesson of Experience 4thEd.McGraw Hill Irwin.

Huxham, C., \& Vangen, S. 2000. Leadership in the Shaping and Implementation of Collaboration Agendas: How Things Happen in a (not Quite) Joined-up World. Academy of Management Journal.

Mardiyah. 2015. Kepemimpinan Kiai dalam Memelihara Budaya Organisasi. Yogyakarta: Aditya Media Publishing.

Mastuhu.1994. Dinamika Sistem Pendidikan Pesantren: Suatu Kajian tentang Unsur dan Nilai Sistem Pendidikan Pesantren. Jakarta: INIS.

Milles Mathew B. dan A. Michael Huberman. 2014. Analisis Data Kualitatif. terj. Tjetjep Rohenal Rohidi. Jakarta: UI Press.

Permadi. 1996. Pemimpin dan Kepemimpinan dalam Manajemen. Jakarta: Rineka Cipta.

Qomar, M. 2005. Pesantren, Dari Transformasi Metodologi Menuju Demokratisasi Institusi. Jakarta: Erlangga.

Ridlwan Nasir, R. 2010. Mencari Tipologi Format Pendidikan Ideal Pondok Pesantren di Tengah Arus Perubahan. Yogyakarta: Pustaka Pelajar.

Rogers, Everett dan Rekha Agarwala-Rogers. 1976.Communication in Organizations New York: The Free Press

Siagian, SP. 1987. Teknik Menumbuhkan dan Mengembangkan Perilaku Organisasional. Jakarta: CV. Haji Masagung.

Soebahar, AH. 2013. Kebijakan Pendidikan Islam dari Ordonansi Guru Sampai UU Sisdiknas. Jakarta: PT. Raja Grafindo Persada. 2013. Modernisasi Pesantren Studi Transformasi Kepemimpinan Kiai dan Sistem Pendidikan Pesantren.Yogyakarta: LkiS.

Steenbrink, A. Karel. 1974. Pesantren, Madrasah, Sekolah, Pendidikan Islam dalam Kurun Modern. Jakarta: LP3ES.

Jurnal Darussalam; Jurnal Pendidikan, Komunikasi dan Pemikiran Hukum Islam Vol. XI, No 2:424-448. April 2020. ISSN: 1978-4767 (Cetak), ISSN: 2549-4171(Online) Terakreditasi Nasional. SK. No.36/E/KPT/2019 
Vianen, A.2000. Person-Organization Fit: The Match beetwen Newcomers' and Recruiters' Preferences for Organization Culturea, Personnel Psychology, Vol. 53.

Wart, Van, M. 2003. Public-Sector Leadership Theory: An Assessment. Public Administration Review.

Whitfield, D.. 2004. Global Leadesrship Competencies", Gonzaga UniversityDoktoral Program School of Professional Studies, $6^{\text {th }}$ Annual Conference November 4-7. Washington DC.

Wisnu, D, dan Siti Nurhasanah. 2005. Teori Organisasi, Struktur dan Desain. Malang: UMM Press.

Jurnal Darussalam; Jurnal Pendidikan, Komunikasi dan Pemikiran Hukum Islam Vol. XI, No 2:424-448. April 2020. ISSN: 1978-4767 (Cetak), ISSN: 2549-4171(Online) Terakreditasi Nasional. SK. No.36/E/KPT/2019 